DOI: $10.2478 / \mathrm{v} 10025-010-0038-1$

JOURNAL OF WATER

AND LAND DEVELOPMENT

J. Water Land Dev. No. 13a, 2009: 329-345

\title{
Premises for the construction of balance equations of water losses in mountain forest soils
}

\author{
Józef SULIŃSKI, Rafat STARZAK
}

University of Agriculture in Krakow, Department of Forest Engineering, al. 29 Listopada 46, 31-425 Kraków, e-mail: rlsulins@cyf-kr.edu.pl

\begin{abstract}
The paper presents premises for the construction of equations of water budget in the atmosphere-tree stand-soil system with reference to water losses in mountain forest soils. The premises were based on results of a long-term forest-hydrologic studies carried out by authors in the Beskid Śląski. Water properties of grounds in soil profiles and specific hydrologic properties of these profiles were considered. The main factors affecting water balance on slopes were orographic conditions, the share of skeleton parts in soil profile and the tree stand. Therefore, the equations of water loss in soil should consider: 1) the input of solar energy over tree crowns and coefficient of energy transmission within tree stand, 2) wind velocity above and within tree stand, 3) elements of water budget in the atmosphere, 4) differentiation of hydrologic properties in soil profiles dealt with as a continuum, 5) water properties of grounds constituting soil profiles with particular reference to organic matter.
\end{abstract}

Key words: forest hydrology, water budget in forest, water budget in soil, water resources in soil

\section{INTRODUCTION}

The paper deals with water reserve in soil and factors affecting its dynamics in mountain forest soils. The reserve means the amount of water stored in soil particles and skeleton (including rocky) particles expressed in volume or in water layer in linear units. These measures referred to the unit volume of the medium may be compared without restrictions among various profiles.

In forest-hydrologic studies water reserve in soil is treated as one of the components of water budget in the atmosphere-tree stand-soil system. Balance equations of water reserve in soils have been used for over 100 years to calculate the components of water budget in tree stands (MolchANOV, 1953; 1960). The amount and dynamics of water reserves is the main factor affecting the productive potential of forest habitat. From the standpoint of water balance in a catchment, water reserve is similar, but not identical, with the notion of soil retention being the main common element of water budget in forest ecosystem and in the catchment. 
Calculation of water reserve in soil profile requires to: (1) measure soil moisture, (2) determine necessary water properties of soil, (3) calculate the reserve using procedures adapted to various aspects of water occurrence in soil (KUCZA, 2005). In mountain conditions the reserve of soil water may practically be calculated to the depth where manual detachment and excavation of rock material is still possible. The measurement of water reserve in soil profile with sufficiently short time intervals enables calculation of its real losses and, under favourable hydrogeologic conditions, also its increments. Application of balance equations for water in soil divided into the phases of losses and increments (Fig. 1) brought new possibilities of calculating and interpreting the components of water budget in forest communities (SULIŃSKI, 1989; 1993).

a)

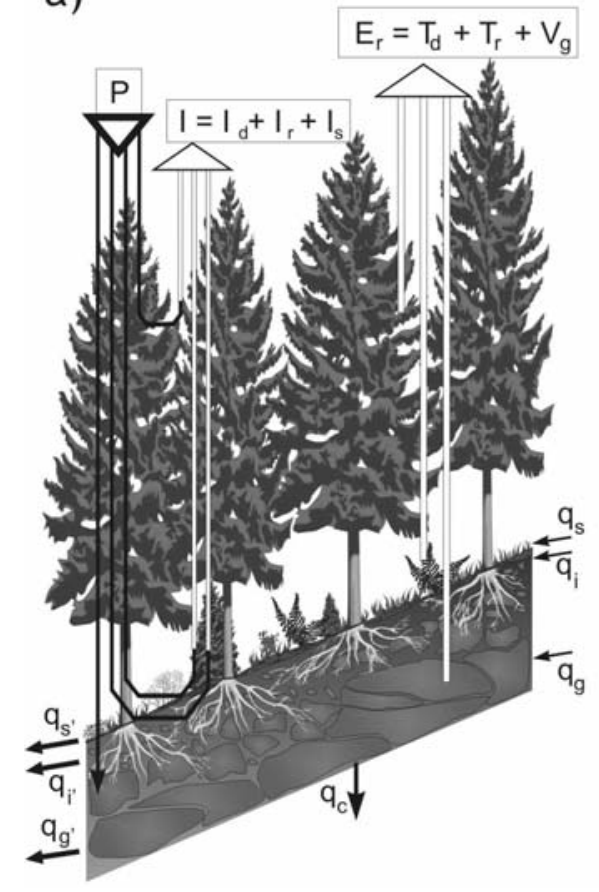

b)

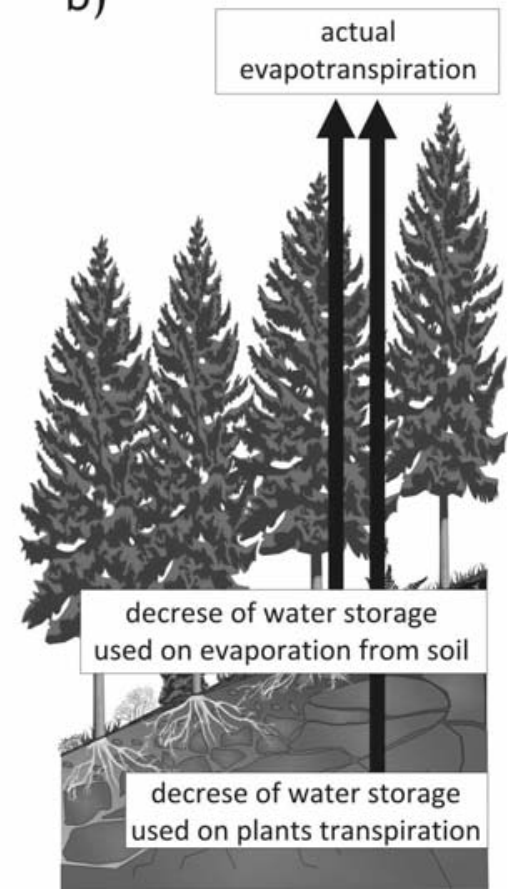

Fig. 1. A scheme of water exchange between atmosphere, tree stand and soil: a) illustration of the phases of soil water loss and recharge; b) illustration of premises of adaptation of general equation (1) to identification based on measured elements of equation (7)

The development of methods of water balancing between atmosphere, tree stand and soil is an urgent task from both research and practical point of view. Long comparative studies on the water runoff from variously forested catchments and intensively developed methods of mathematical modelling did not answer the key questions pertaining to water relations in forest areas, in particular the relation- 
ships between forest management and the water budget of forest ecosystem (LEE, 1980; Johnson, 1998; SWANK et al., 2001; Chang, 2003; PiKe and SCHERER, 2003). In such situation foresters are forced to undertake economic decisions without sufficiently precise practical tools for diagnosing and predicting water relations in forests in the context of both forest productivity and water runoff. It seems that solution of the problem might be in the already mentioned balance equations of water reserve in soil (SULIŃSKI, 1993; 1995). If quantitative relations between the dynamics of water reserves in soil and biometric features of the tree stand are proven than it will be possible to forecast the dynamics of water reserve in a definite soil profile and between profiles based on easily predictable changes of these features. Equations constructed in this convention are destined to diagnose and forecast the dynamics of soil water reserves changing due to economic activities, forest transformations associated with biotic and abiotic factors, the impact of manmade constructions on water relations in forest ecosystems etc.

The aim of this paper was to propose the balance equation that would describe water losses from mountain forest catchment based on premises called by CZARNOWSKI (1978) "ecologic criteria" and then to identify it by field measurements. The equation is valid for periods without snow cover.

\section{THE MAIN PREMISES TO CONSTRUCT EQUATIONS OF WATER BALANCE IN THE ATMOSPHERE-TREE STAND-SOIL SYSTEM IN MOUNTAIN AREAS}

Problems presented in this paper belong to the research current that seeks the explanation of factors differentiating the dynamics of water reserves in tree stands (SULIŃSKI, 1995). The factors may be divided into "external" and "tree-stand related" (Fig. 2). If the effect of tree stand is studied observing the principle ceteris paribus with respect to external factors then the obtained results may be identified with relations between the features of tree stand and components of water balance in the atmosphere-tree stand-soil system.

Dominating external factors include atmospheric precipitation, potential evapotranspiration above tree crowns and hydro-geologic conditions. Potential evapotranspiration (drying air ability (CZARNOWSKI, 1978)) is determined by solar energy and wind velocity. Direct measurement of these factors in a given forest ecosystem is possible in special station set up for gradient measurements (SULIŃSKI et al., 2006) or in the close vicinity in open area where atmospheric precipitation can also be measured. When selecting the site for measurements one has to consider location of studied ecosystem, the same elevation, exposition and slope. These requirements are hard to meet in forests therefore, when planning the base for measurements one often chooses simplified solutions. 


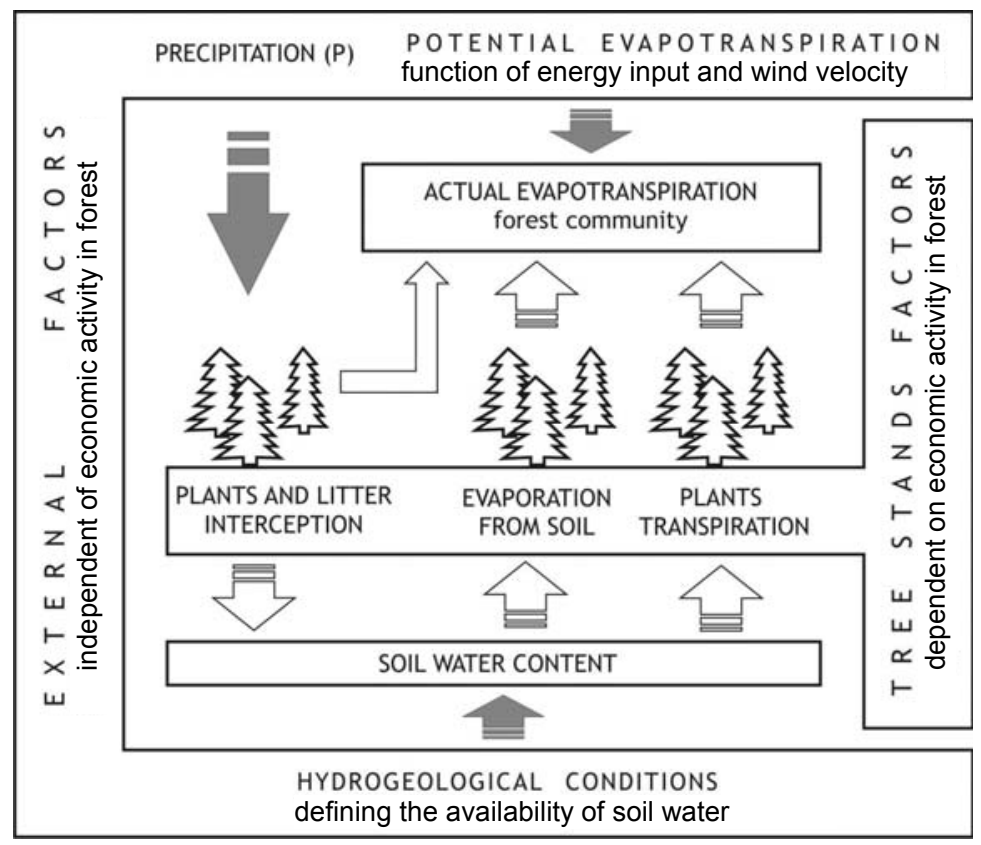

Fig. 2. Factors affecting water balance in forest ecosystem

Hydro-geologic conditions as an external factor affecting the occurrence and dynamics of water reserves depend mainly on the properties of rocky substratum and the thickness and mechanical features of the soil. Water capacity of soil profile markedly decreases with increasing elevation. Some deviations from this rule may be found within the confines of mass soil movements and in the valley bottoms. On slopes, the occurrence of water reserves in soil is associated mainly with the aeration zone. Saturation zone does not exist or may occur periodically. Permanent saturation zones may be found locally in depressions running parallel to the slope inclination or in the valley bottom.

Credible calculation of water reserve in mountain soil needs complex procedures and is burdened by some risk of error (KUCZA, 2005). Particularly difficult is precise determination of water properties of soil at its contact with rocky substratum especially if there is ground water there whose flow is not continuous. Possible differences between inflowing and outflowing water may largely contribute to water balance calculated for the aeration zone (Fig. 1). These difficulties demand careful selection of study profiles based on detailed studies of hydro-geologic conditions.

Forest soils have specific hydrologic properties. Discontinuity of the soil medium and the presence of organic matter are most important for water reserves. The former is associated with the presence of live and dead roots, contact zones of soil with rock grains and cobbles and tunnels dug by soil fauna. These discontinuities 
make rainfall or water from melting snow infiltrate down the soil profile and eventually flow out before water capacity of soil and rock particles in the whole profile is filled up.

Hydrologic properties of organic matter in the organic soil horizon and beneath are not fully understood. Results of field and laboratory studies indicate the dominating role of decomposition and mineralization (SULIŃSKI, 1993; KUCZA and URBAŚ, 2005; KUCZA, 2007) which determine bulk density, field water capacity, permeability, shrinkage and other properties (e.g. STARZAK, 1998; KUCZA and SULIŃSKI, 2000; MYŚLIŃSKA, 2001; HOMA, 2003; KUCZA, 2007). The importance of the variable properties of skeleton parts such as mineralogical composition and structure, proportion, grain size and the degree of surface weathering should also be underlined. These features are important for the moisture of skeleton parts and their border with earth particles. It is practically impossible to measure moisture of rock particles. Including water reserves from these particles to the water balance of the whole profile is only possible by combining the dynamics of this reserve with the dynamics of water reserves in soil. Such approach was adopted in the original method of calculating water reserves in soil profile proposed by KUCZA (2005). The method which meets the demand for constant place of measurement in the soil profile for a longer time period was successfully applied in studies on water budget in soils of the Beskid Ślaski (KUCZA et al., 2005; STARZAK, 2006). Selected results of this study are used in this paper.

In the context of presented premises it is worth noting that hydrologic properties of all forest soils, and skeleton mountain soils in particular, referred to the whole soil profile very often assume values markedly different from those which were determined in samples.

\section{CONSTRUCTION OF THE EQUATION OF LOSSES IN SOIL WATER RESERVE}

Solving the equations of water budget in soil is dealt with as one of the basic methods in studying water budget in forest ecosystems (SULIŃSKI, 1993). It is a base for estimating, to what degree the components of the budget are differentiated by tree stand properties. Progress in such studies determines the development of methods of diagnosing forest habitats and predicting changes in water relations associated with tree stand growth, management or with the impact of biotic and abiotic factors. The method implies adaptation of the general equation to a form that would meet specific demands required in an undertaken task and then identification based on data from many soil profiles localised in tree stands of different biometric features.

Water budget in atmosphere-tree stand-soil presented in Fig. 1 may be divided into two phases - losses and recharge of soil water reserves. So divided balance 
equations enable deeper insight into the mechanism of "vertical exchange" of water in a forest (Fig. 1). In the phase of water losses the starting points is the equation in a general form (SULIŃSKI 1993):

$$
Z_{u}=\left(T_{d}+T_{r}\right)+V_{g}+\left(q_{s}-q_{s^{\prime}}\right)+\left(q_{i}-q_{i^{\prime}}\right)+\left(q_{g}-q_{g^{\prime}}\right)+q_{c}
$$

where:

$Z_{u}-$ loss of soil water reserve,

$T_{d}$ - transpiration of trees,

$T_{r}$ - transpiration of undergrowth,

$V_{g}$ - evaporation from soil surface,

$q_{s}$ - inflow of surface,

$q_{s}, \quad$ outflow of surface,

$q_{i}$ - inflow of subsurface,

$q_{i}$, - outflow of subsurface,

$q_{g}$ - inflow of ground,

$q_{g^{\prime}} \quad-$ outflow of ground,

$q_{c}$ - outflow to deeper layers not included in the budget.

Equation (1) has a universal character; it may be used for lowland, submountain and mountain forest ecosystems. Detailed form of the equation should be related to the aim of budget calculations and to possibilities of data acquisition for its identification. In practice it means the replacement of independent variables that could not be measured in forest ecosystem by equivalent variables whose measurement is possible. The case presented in this paper served to verify the hypothesis that differentiation of water losses from soil reserves in spruce tree stands of the same age in the Beskid Śląski can be expressed by biometric features of tree stands (STARZAK, 2006) as it was in pine tree stands of Niepołomicka Forest (SULIŃSKI, 1993).

A scheme presented in Fig. 1b was used in the adaptation of balance equation (1) to the verification of assumed hypothesis. Authors had data (Tab. 1) to identify constructed equation. The site and way of their collection is described below.

In the phase of water losses from soil reserves the main external factor is the potential evapotranspiration above tree crowns. It is a resultant of solar energy and wind speed over tree crowns. When adapting the equation to verifiable form it was assumed that potential evapotranspiration can be expressed by daily mean deficits of air humidity. They were calculated for each of 15 sampling sites with the use of records from meteorological station situated in a mid-forest meadow. Calculation periods were adjusted to the terms of occurrence of water losses in every site, hence large variation of obtained values (Tab. 1). In the mountains these factors are highly differentiated depending on terrain orography, elevation, exposition and 


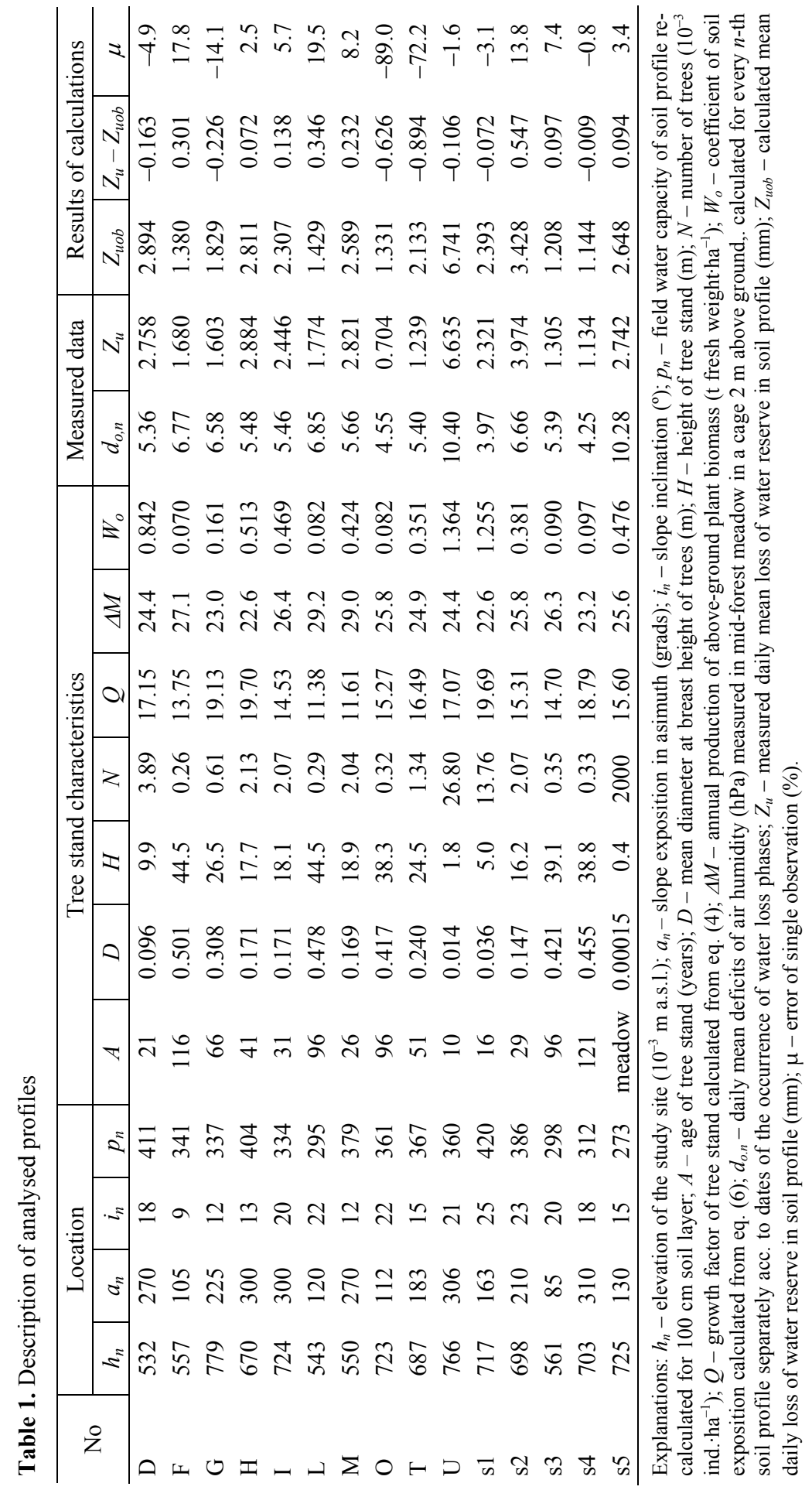


slope. The effect of orographic factor was expressed in constructed equation as follows:

$$
d_{n}=\left(d_{o, n} \frac{\mu}{h_{n}}\right)\left[2-\left(\left(\frac{a_{n}}{400}-\gamma\right)^{2}\right)^{\frac{i_{n}}{90}}\right]
$$

where:

$d_{n}$ - daily mean deficit of air humidity for $n$-th site, $\mathrm{hPa}$;

$d_{o, n}$ - daily mean deficit of air humidity (hPa) measured in mid-forest meadow $2 \mathrm{~m}$ above ground for each $n$-th soil profile separately acc. to dates of the occurrence of water losses from soil reserves;

$h_{n}$ - elevation of the measurement site, $10^{-3} \mathrm{~m}$ a.g.l.;

$a_{n}$ - slope exposition expressed in azimuth, grads;

$i_{n} \quad-$ slope, ${ }^{\mathrm{o}}$;

$\mu, \gamma-$ coefficients calculated in the process of identification of the equation (7).

Equation (2) is empirical though based on premises whose effect on differentiation of deficits in air humidity due to terrain orography is known.

The following assumptions were adopted as to the effect of ,horizontal” water flow (Fig. 1) on soil water reserves in the phase of its losses: (1) water flow on soil surface did not happen even after heavy rains i.e. equation (1) may be simplified by taking $\left(q_{s^{\prime}}-q_{s}\right)=0$; (2) water flow in the ground, if present in a given profile, is similar to continuous flow, so $\left(q_{g^{\prime}}-q_{g}\right)=0$; (3) no subsurface flow was found i.e. $\left(q_{i^{\prime}}-q_{i}\right)=0$; (4) the amount of water permeating from soil to rock substratum is negligibly small, then $q_{c} \sim 0$. These assumptions are a result of measurements on five plots on slopes and observations in the remaining ten measurement sites. Similar results were obtained in experimental catchment of the Ratanica River in Pogórze Wielickie (SULIŃSKI and KUCZA, 1993). Measurement sites were purposefully located far from watershed division line to minimise possible effect of discontinuous water flow. Described assumptions were adopted after analyses of the amount and time distribution of ground outflow based on a hydrograph from the profile closing the catchment basin. The least documented was the assumption of $q_{c} \sim 0$, nevertheless, it does not rise objections in the phase of water losses.

If one eliminates the effect of external factor variability and of possible unstable horizontal inflow and outflow of water (Fig. 1) then water losses from soil reserves may be expressed as a sum of water taken for transpiration and that directly evaporated from the soil surface. Transpiration of plants is proportional to produced biomass; therefore in a given forest ecosystem total transpiration of all plants is proportional to forest productivity:

$$
T_{d}+T_{r}=\alpha \lambda \Delta M
$$


where:

$T_{d}+T_{r}-$ mean daily transpiration of all plants in tree stand, $\mathrm{mm}$;

$\alpha \quad-$ mean daily consumption of water for transpiration - coefficient calculated during identification of the equation, $\mathrm{mm} \mathrm{H}_{2} \mathrm{O} \cdot(\mathrm{t}$ fresh weight $)^{-1} \cdot \mathrm{ha}^{-1}$;

$\lambda$ - proportion of day hours in the vegetation period (CZARNOWSKI, 1978) for the calculation time period

$\Delta M \quad$ - annual production of above-ground plant biomass calculated form eq. (4), $\mathrm{t}$ fresh weight $\cdot \mathrm{ha}^{-1}$;

Annual biomass production $\Delta M$ may be estimated with the method of SULIŃSKI (2007) from equation:

$$
\Delta M=\delta+\omega \mathrm{e}^{-0.0455 Q}
$$

in which

$$
Q=\frac{A}{\mathrm{e}^{\frac{1}{2 \eta} H_{A>A_{m}}+0.386}-1}
$$

where:

$\delta, \omega \quad$ - species-specific coefficients, for spruce $\delta=8.2$ oraz $\omega=35.3$;

$Q \quad$ - growth factor of tree stand;

$A \quad$ - age of tree stand, years;

$H_{A>A m}-$ mean height of tree stand (m) in the age $A>A_{m}$, where $A_{m}=0.617 \eta$; for spruce $\eta=11.97$.

Evaporation from soil surface within the tree stand in relation to that from open area may be expressed by the coefficient of soil exposition (SULIŃSKI 1993):

$$
V_{n}=V_{g, \max }\left(1-e^{-4 W_{o}}\right)
$$

where:

$V_{n} \quad$ - evaporation from soil surface covered by forest vegetation;

$V_{g, \max }$ - evaporation from ,bare soil”;

$W_{o} \quad$ - coefficient of soil exposition calculated from eq. (6).

Coefficient $W_{o}$ of soil exposition was constructed with the assumption that evaporation from the soil surface is mainly determined by solar energy and wind speed within tree stand. Base data for estimating their relative values in a given tree stand were solar energy and wind velocity above tree crowns i.e. the external factors whose variability in the valley were related to elevation, exposition and slope acc. to eq. (2). Based on these assumptions, the coefficient of soil exposition $W_{o}$ was related to biometric features of tree stands acc. to equation (SULIŃSKI, 1993): 


$$
W_{o}=(\Sigma d)^{2} \frac{1}{1+H \sqrt{N}}
$$

where:

$W_{o}$ - coefficient of soil exposition due to the transfer of solar energy and slowing down wind speed within tree stand;

$\Sigma d$ - sum of diameters at breast height of trees in a tree stand, $10^{-2} \mathrm{~m} \cdot \mathrm{ha}^{-1}$;

$H$ - height of tree stand, m;

$N$ - number of trees, $10^{-3}$ ind. $\cdot \mathrm{ha}^{-1}$.

The amount of evaporating water depends not only on conditions above the soil surface but also on the amount of water available in the soil. Therefore, when constructing eq. (7) we looked for such a feature of soil profile that would reflect the differences in available water between studied profiles. For lowland forest soils we used gravitational permeability. More useful for mountain soils was the field water capacity estimated in soil samples taken from several depths and then averaged for the whole soil profile and recalculated for $100 \mathrm{~cm}$ thick soil layer.

Equation (1) adjusted for identification based on obtained database assumed the final form:

$Z_{u}=\alpha \lambda \Delta M+\beta\left(1-e^{-4 W_{o}}\right)\left(\left(\frac{d_{o, n}}{d_{o, n, \max }}\right)^{\frac{\mu}{h_{n}}}\right)\left[2-\left(\left(\frac{a_{n}}{400}-\gamma\right)^{2}\right) \frac{i_{n}}{90}\right]\left(\left(\frac{p_{n}}{p_{n, \max }}\right)^{3}\right)$

where:

$Z_{u} \quad-$ mean daily water loss from soil profile, $\mathrm{mm}$;

$\Delta M \quad-$ annual biomass production of above-ground plant parts, $\mathrm{t}$ fresh weight $\cdot h a^{-1}$;

$\lambda-$ proportion of day hours (CZARNOWSKI, 1978) in the study period to entire vegetation period - for the case in question $\lambda=$ $1320 / 2818=0.468$;

$W_{o} \quad-$ dimensionless coefficient of soil exposition in tree stand calculated from eq. (6);

$d_{o, n} \quad$ - daily mean deficits of air humidity measured in mid-forest meadow in a cage $2 \mathrm{~m}$ above ground calculated for each $n$-th soil profile separately acc. to the dates of the occurrence of loss phases, $\mathrm{hPa}$;

$d_{o, n, \max } \quad-$ maximum value of $d_{o, n}$ among data from 15 measurement sites (tab. 1);

$h_{n} \quad-\quad$ elevation of the site, $\mathrm{m}$ a.s.l.;

$a_{n} \quad-$ slope exposition, grads; 


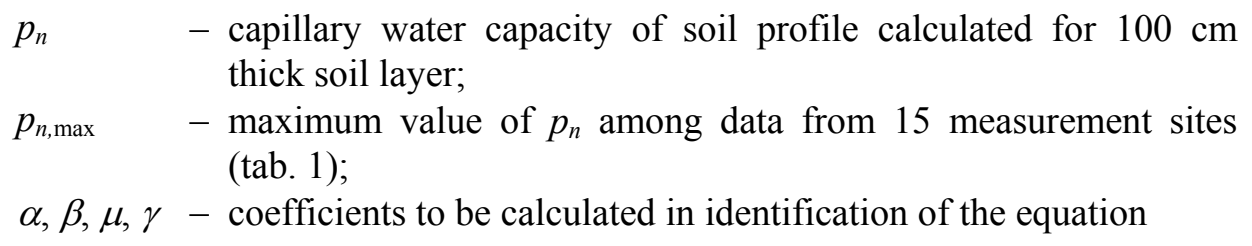

\section{RESULTS OF IDENTIFICATION OF EQUATION (7)}

Data used to identify equation (7) originate from experimental catchment basin of the Dupniański Brook $\left(1.68 \mathrm{~km}^{2}\right)$, a right tributary of the Olza River. The catchment is situated in south-western part of the Beskid Ślaski, in the Wisła Forest Commission belonging to the Forest Promotional Complex - the Beskid Śląski Forests. It was designed and equipped by the team of the Department of Forest Engineering, Faculty of Forestry, Hugo Kołłątaj Agricultural University in Cracow and financed by the Regional Authority of State Forests in Katowice (SULIŃSKI et al., 1997; 2001).

Water losses from soil reserves set up in table 1 were measured from $8^{\text {th }}$ May till $11^{\text {th }}$ October 2005 in three series: in spring $\left(08^{\text {th }}\right.$ May $-07^{\text {th }}$ June $)$, early summer $\left(14^{\text {th }}\right.$ July $-11^{\text {th }}$ August $)$ and late summer $\left(07^{\text {th }}\right.$ September- $11^{\text {th }}$ October $)$, which together lasted 93 days. Soil moisture was measured with the electro-resistance method (MALICKI, 1980; KUCZA, 2005) at least once a day at three to four depths in 14 soil profiles situated in spruce tree stands and in one profile situated in a midforest meadow. The study profiles were selected in tree stands of highly variable quality features (Tab. 1). Five of these profiles were localised in study plots involved in the full measurement programme (surface runoff, ground water table depth measured in piesometers pressed to the level of parent rock). Atmospheric precipitation, temperature, air humidity, solar energy, wind direction and velocity were measured in a meteorological station situated in abandoned mid-forest meadow - site s5 (Tab. 1). Water outflow from the catchment was recorded continuously.

Measurements of moisture, estimation of soil properties and calculation of soil water reserves were made acc. to the method of KUCZA (2005). The phases of water losses from soil reserves were estimated for every profile acc. to dates of the occurrence of extreme values distinguishing them from the phases of water increments in a way illustrated in Fig. 3. Losses in a given profile were summed up and divided by the number of measurements to obtain daily mean loss of water reserve in the whole soil profile. Adoption of the daily time step enabled possibly precise distinction of subsequent phases of recharges and losses but also assignment of the deficits of air humidity and atmospheric precipitation measured on mid-forest meadow with the observation of threshold dates of phases of water loss in particular profiles (Fig. 3). 

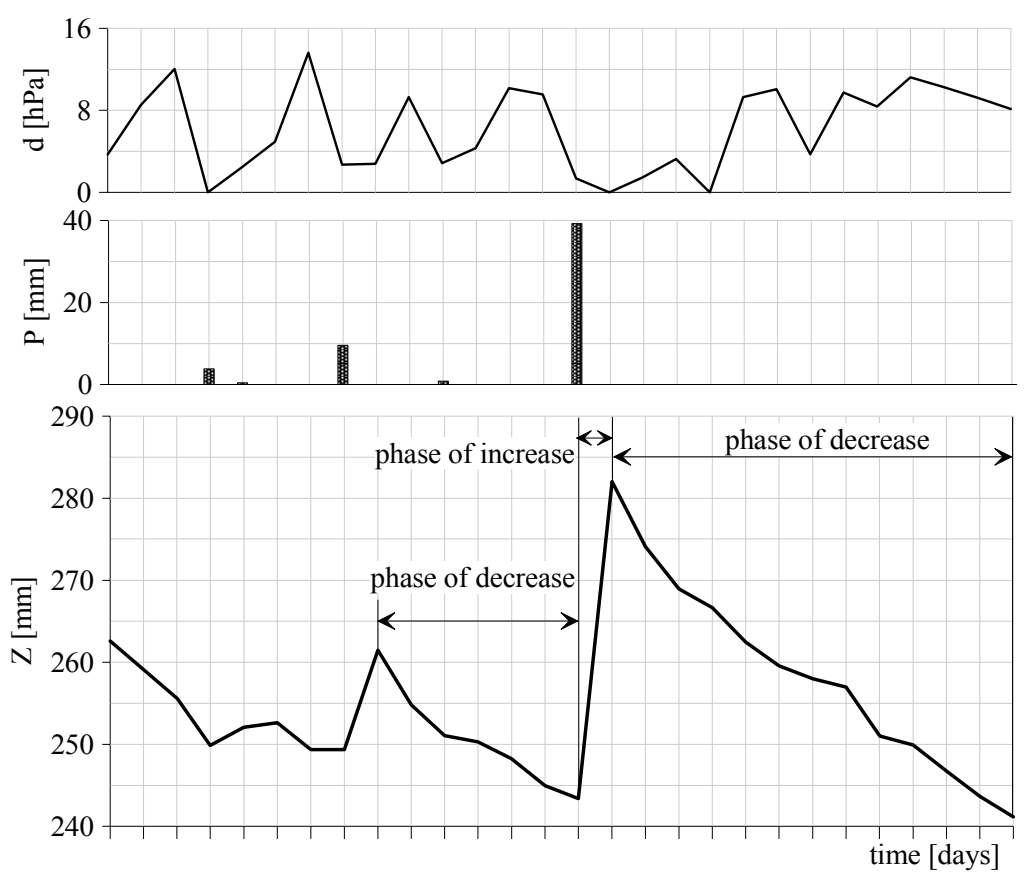

Fig. 3. An example of distinguishing the phases of water increments and losses in soil; $d$-deficit of air humidity, $P$ - atmospheric precipitation, $Z$ - water reserve in soil

Coefficient $\alpha, \beta, \mu, \gamma$ calculated in the process of identification of equation (7) and the agreement of calculated and measured water losses are set up in Table 2. Explanation of the variability of mean daily water losses in 15 profiles by independent variables used in eq. (7) $100 R^{2}=93.6 \%$ is considered high in field studies and confirms proper construction of the equation. Mean error of estimate $\sigma=0.366$ $\mathrm{mm}$ constituted $15.2 \%$ of the mean water losses measured in 15 profiles and was markedly higher than that obtained for lowland tree stands (SULIŃSKI, 1993). It was an effect of two profiles marked $\mathrm{O}$ and $\mathrm{U}$ (Tab. 1). They showed the highest errors of single records ( 89 and $72 \%$, respectively) but the lowest water losses measured there resulted in that even small differences caused high percentage error (Fig. 4). Errors in other profiles were relatively small which was reflected by re-

Table 2. Results of identification of eq. (7) for 15 soil profiles with the use of data from Table 1

\begin{tabular}{|c|c|c|c|c|c|c|c|c|c|c|c|}
\hline \multirow{2}{*}{\multicolumn{4}{|c|}{$\begin{array}{l}\text { Coefficients calculated } \\
\text { in identification }\end{array}$}} & \multicolumn{8}{|c|}{ Agreement between calculated and measured values (Tab. 1) } \\
\hline & & & & \multirow{3}{*}{$\begin{array}{c}\text { number of } \\
\text { cases }\end{array}$} & \multirow{3}{*}{$100 R^{2}$} & \multicolumn{2}{|c|}{ mean error } & \multicolumn{4}{|c|}{ error of a single case, $\%$} \\
\hline \multirow{2}{*}{$\alpha$} & \multirow{2}{*}{$\beta$} & \multirow{2}{*}{$\mu$} & \multirow{2}{*}{$\gamma$} & & & \multirow{2}{*}{$\begin{array}{c}\sigma \\
\mathrm{mm}\end{array}$} & \multirow{2}{*}{$\begin{array}{r}v \\
\%\end{array}$} & \multicolumn{2}{|c|}{ maximum } & \multicolumn{2}{|c|}{ quartile } \\
\hline & & & & & & & & + & - & + & - \\
\hline 0.0842 & 5.518 & 1.276 & 0.672 & 15 & 93.6 & 0.366 & 15.2 & 19.4 & 89.0 & 7.9 & 5.2 \\
\hline
\end{tabular}


a)

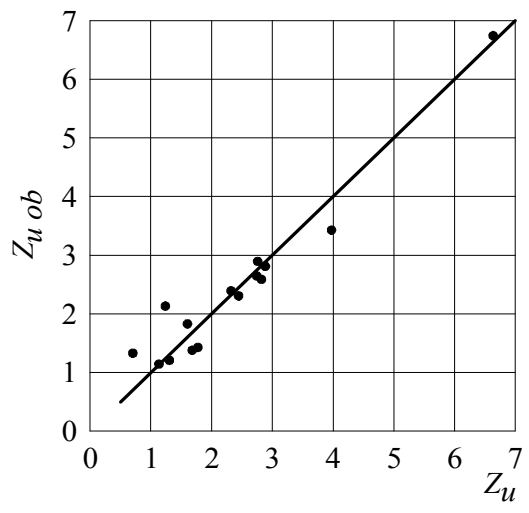

b)

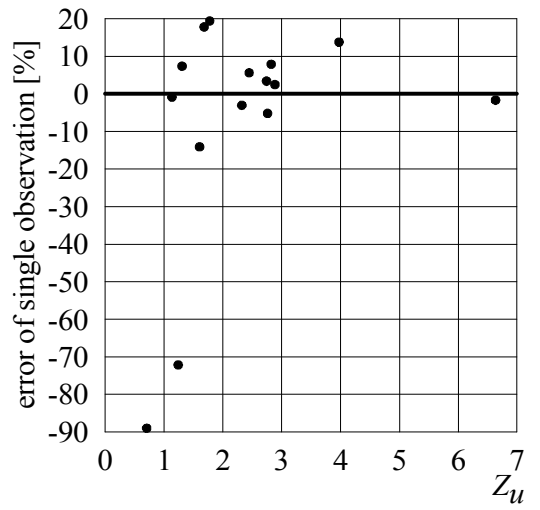

Fig. 4. Illustration of the accuracy of eq. (7): a) comparison of measured $Z_{u}$ and calculated $Z_{u o b}$ daily mean water losses, b) errors of single observation for $Z_{u}$

spective quartiles (Tab. 2). The significance of partial regression coefficient of $\alpha, \beta, \mu, \gamma$ were verified with t-test with highly positive result.

Results of identification of equation (7) allow for analysing the effect of characteristics of the studied tree stands on differentiation of water losses from soil reserves since they conform to the principle ceteris paribus in relation to external factors. Plant transpiration and evaporation from the soil surface will be considered.

Daily mean transpiration of all plants in forest community is expressed in eq. (7) by the element $\alpha \lambda \Delta M$. Annual above-ground biomass production ranged there from 29.2 do $22.6 \mathrm{t}$ fresh weight per hectare (Tab. 1). If one assumes that production is proportional to the number of day hours (CZARNOWSKI, 1978), than the biomass increment in 93 days of measurement may be estimated as $\lambda=1320 / 2818$ $=0.468$ part of annual production. Incorporation of this coefficient to eq. (7) makes that the $\alpha$ value obtained during identification means the amount of water transpired daily per $1 \mathrm{t}$ of fresh biomass of above-ground plant parts produced on 1 ha in 1 year. By multiplying $\alpha=0.0842$ by 198 days of the vegetation period $\left(15^{\text {th }}\right.$ April till $30^{\text {th }}$ October) we obtain the value of habitat coefficient of transpiration equal $16.6 \mathrm{~mm} \mathrm{H}_{2} \mathrm{O}$. The same coefficient calculated from the balance of soil water in pine tree stand of Niepołomicka Forest was $15.5 \mathrm{~mm}$ (SULIŃSKI, 1993). Noteworthy, spruce is the species using two times less water for transpiration than pine - a conclusion drawn, however, from measurements of single individuals (CZARNOWSKI, 1978).

Mean daily water losses from soil $Z_{u}$ for 93 days of measurements due to evaporation from the soil surface ranged between 6.74 and $1.14 \mathrm{~mm}$ (Tab. 1). Their variability was the main reason of variable water losses from soil reserves. It 
should be underlined, however, that eq. (7) does not eliminate possible effect of evaporation of water stored as an effect of forest litter interception.

Water losses calculated from eq. (7) increase with the soil exposition and with the increase of air humidity above ground. In tree stands of the same age $W_{o}$ assumes maximum values when undergrowth disappears under the closing canopy of young trees and the soil is maximally exposed. Then the losses of water reserves for evaporation are the highest (Fig. 5). This result fully agrees with the dynamics of water relations in lowland forests (SULIŃSKI, 1993) except for profile s5 in midforest meadow where evaporation from soil surface was unexpectedly high. It should be mentioned, that meadow productivity (Tab. 1) was estimated acc. to that of neighbouring forest communities while the coefficient of exposition $W_{o}$ was calculated from eq. (6). So, it was assumed that meadow vegetation is a specific model of forest vegetation (SULIŃSKI, 1993). This view is justified (CZARNOWSKI, 1978) but not verified experimentally in mountain conditions.

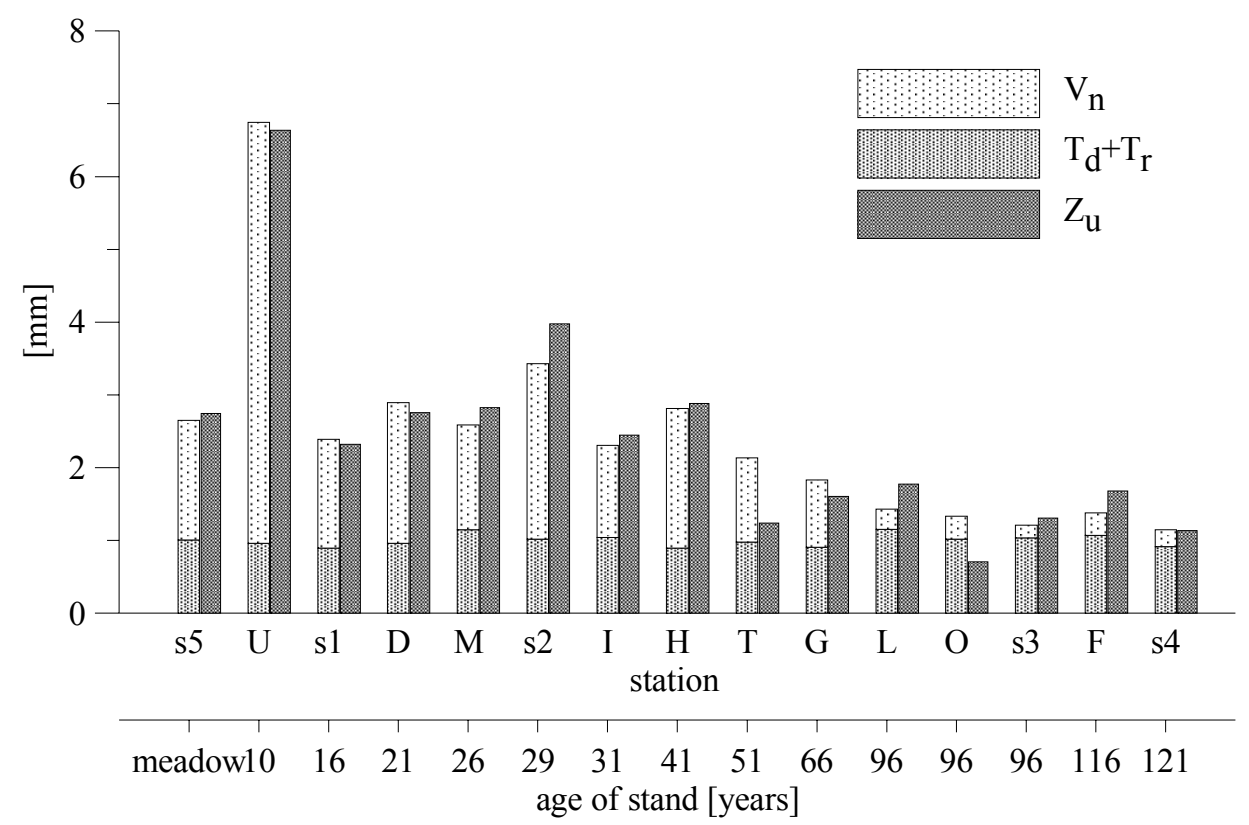

Fig. 5. Calculated from eq. (7) $Z_{u o b}\left(T_{d}+T_{r}+V_{n}\right)$ and measured $Z_{u}$ daily mean water losses from soil

Slope exposition differentiated water losses according to expectations. The largest losses of water from soil occurred ceteris paribus on slopes for which $\gamma=$ 0.672 which corresponded to the asimuth $269^{\mathrm{g}}$ i.e. to the south-western exposition. The importance of slope exposition is also associated with slope inclination - when the terrain is flat the effect disappears and increases with the increase of inclination. 


\section{SUMMARY AND CONCLUSIONS}

An attempt was undertaken of constructing balance equation to explain variability of water losses from soil reserves by experimentally measured productivity of forest habitats and selected biometric features of tree stands. The equation was adapted to the database of measured soil water reserves in 15 profiles of forest soils in the experimental catchment of the Dupniański Brook in the Wisła Forest Commission being part of the Forest Promotional Complex - the Beskid Śląski Forests. Results of measurements performed in 2003 in three series covering in total 93 days were used. Positive identification of the equation confirms the thesis that it is possible to quantitatively present the relationship between water losses and biometric features of tree stands in mountain forest soils.

Constructed equation (7) might be a practical example of modelling water budget in order to estimate water losses due to the development of tree stand, management practices, biotic and abiotic factors and to other factors affecting water relations in a forest. Calculated coefficients pertain only to studied conditions but the equation (7) itself has a universal character and may be identified based on another set of data.

Positive effect of identification of eq. (7) allows for formulating conclusions on general rules of forest ecosystem functioning. The agreement of the coefficient of habitat transpiration $\alpha=16.6 \mathrm{~mm}$ calculated for spruce tree stands with $\alpha=15.5$ $\mathrm{mm}$ for pine tree stands in Niepołomicka Forest is an additional evidence for two key hypotheses important for explaining water budget in forest communities formulated by SULIŃSKI (1993): (1) the amount of water used for transpiration is proportional to produced biomass regardless of habitat quality and (2) at the level of forest ecosystem the amount of water used for transpiration does not depend on plant species. Having in mind that transpiration coefficient calculated for plant growing alone is species-specific (CZARNOWSKI, 1978) the obtained results indirectly confirms the ecological principle that plant features considered at individual's level of life organisation may give in to the features of a community considered at the level of forest ecosystem

\section{REFERENCES}

1. Chang M., 2003. Forest hydrology: an introduction to water and forests. Boca Raton, London, New York, CRC Press.

2. CZARnowsKi M. S., 1978. Zarys ekologii roślin lądowych. (Outline of terrestrial plants ecology). Warszawa, PWN.

3. Нома A., 2003. Retencja opadu w ściółce leśnej w karpackiej zlewni badawczej potoku Trzebuńki. Kraków, PKrak. maszyn.

4. Johnson R., 1998. The forest cycle and low river flows: a review of UK and international studies. Forest Ecol. Manag., 109: 1-7. 
5. KuCZA J., 2005. Teoretyczne i praktyczne aspekty obliczania zapasu wody w glebach leśnych. Cz. 2. Gleby szkieletowe. (Theoretical and practical aspects of calculating water resources in forest soils. Part II. Skeletal soils). Sylwan 149, 10: 35-46.

6. KuCZA J., 2007. Właściwości hydrologiczne materii organicznej gleb leśnych na przykładzie gleb pod świerczynami istebniańskimi. (Hydrological properties of organic matter of forest soils as exemplified by soils under Istebna stands of Norway spruce). Zesz. Nauk. AR Krak, Ser. Rozpr., 442.

7. KuCZA J., SuliŃSKi J., 2000. Relacje pomiędzy porowatością kapilarną a gęstością objętościową i kurczliwością gruntów o różnej zawartości części organicznych, występujących na terenie zlewni doświadczalnej Potok Dupniański w Beskidzie Śląskim. (Capilloary water capacity related to the bulk density and contraction volume in soils with various fractions of organic matter, occurring in the catchment of Dupniański stream in the Beskid Śląski range). Acta Agr. Silv. Ser. Silv., 38: 91106.

8. KucZa J., StarZaK R., SuliŃSKi J., 2005. Wstępne wyniki pomiaru zapasu wody w glebie pod świerczynami istebniańskimi. (Initial results of measurements of soil water storage under Norway spruce stands of Istebna region). Czas. Tech., 10-S: 59-70.

9. KUCZA J., URBAŚ J., 2005. Water absorption of organic matter taken from horizons of ecohumus of forest soils under Norway spruce stands. EJPAU Ser. Forestry 8, 4.

10. LEE R., 1980. Forest hydrology. New York, Columbia Univ. Press.

11. MALICKI M., 1980. Systematyka i przegląd metod pomiaru wilgotności gleby. Probl. Agrofiz., 31: 5$-46$.

12. MolchanOv A., 1953. Sosnovyj les i vlaga. Moskva, Izdat. Akad. Nauk SSSR.

13. Molchanov A., 1960. Gidrologičeskaja rol' lesa. Moskva, Izdat. Akad. Nauk SSSR.

14. MYŚLIŃSKA E., 2001. Grunty organiczne i laboratoryjne metody ich badania. Warszawa, PWN.

15. PIKE R. G., SCHERER R., 2003. Overview of the potential effects of forest management on low flows in snowmelt-dominated hydrologic regimes. J. Ecosyst. Manag., 3 (1): 1-17.

16. STARZAK R., 1998. Zatrzymywanie wody przez materię organiczną w nawiązaniu do warunków fizjograficznych zlewni potoku Dupniańskiego w Beskidzie Śląskim. Kraków, Kat. Inż. Leśn. AR pr. magist. maszyn.

17. STARZAK R., 2006. Dynamika zapasu wody w glebach wybranych drzewostanów świerkowych Beskidu Śląskiego. (The water storage dynamics in soils of selected spruce stands in Beskid Slaski). Kraków, AR maszyn.

18. SULIŃSKI J., 1989. Badanie wymiany wody: atmosfera-drzewostan-grunt w wybranych drzewostanach sosnowych zachodniej części Kotliny Sandomierskiej. (Investigation of water exchange: atmosphere-forest stand-ground in selected pine tree stands of the Sandomierz basin western part). Zesz. Nauk. AR Krak., Ses. Nauk., 23, 232: 143-164.

19. SULIŃSKI J., 1993. Modelowanie bilansu wodnego w wymianie miedzy atmosfera, drzewostanem i gruntem przy użyciu kryteriów ekologicznych. (Modelling of water balance in an exchange between the atmosphere, stand and ground using ecological criteria). Zesz. Nauk. AR Krak., Ser. Rozpr., 179: 133.

20. SULIŃSKI J., 1995. Czynniki różnicujące wartości składowych bilansu wodnego drzewostanów zagospodarowanych zrębowo. (Factors differentiating component values of water balance in tree stands managed with clearcutting methods). Sylwan, 139, 11: 49-66.

21. SULIŃSKI J., 2007. Metoda obliczania rocznej produkcji biomasy w zbiorowisku leśnym w zależności od wysokości i wieku drzewostanu. (The tree-stand height and age based method for calculation of annual biomass production in a forest community). Acta Agr. Silv. Ser. Silv., 45: 89-118.

22. SULIŃSKI J., KUCZA J., 1993. Elements of geographical environment and water balance of the Ratanica Stream (Carpathian Foothills, southern Poland). Ekol. Pol., 41, 3-4: 331-346.

23. SULIŃSKI J. et al., 1997. Zbadanie bilansu wodnego świerczyn rasy istebniańskiej. Dokumentacja badań. Kraków, AR, Katowice, RDLP maszyn. 
24. SULIŃSKI J. et al., 2001. Zbadanie czynników określających dynamiką zapasu wody, chemizm i produkcyjność gleb leśnych wytworzonych z piaskowców istebniańskich. Dokumentacja badań. Kraków AR, Warszawa, GDLP maszyn.

25. SULIŃSKI J. et al., 2006, Zbadanie wpływu czynników hydrogeologicznych i drzewostanowych na bilans wodny świerczyn w kontekście ich przebudowy na obszarze Beskidu Śląskiego. Dokumentacja badań. Kraków, AR maszyn.

26. SwANK W., Vose J., ElLiotT K., 2001. Long-term hydrologic and water quality responses following commercial clearcutting of mixed hardwoods on a southern Appalachian catchment. Forest Ecol. Manag., 143: 163-178.

\section{STRESZCZENIE}

\section{Przesłanki do konstrukcji równań bilansowych ubytków zapasów wody w górskich glebach leśnych}

Słowa kluczowe: bilans wodny lasu, bilans wody w glebie, hydrologia leśna, zapas wody w glebie

W pracy przedstawiono założenia do konstrukcji równań bilansu wodnego atmosfera-drzewostan-gleba, w odniesieniu do ubytków zapasu wody w górskich glebach leśnych. Założenia te opracowano na podstawie analizy wyników wieloletnich badań hydrologiczno-leśnych prowadzonych przez autorów na terenie Beskidu Śląskiego. Uwzględniono właściwości wodne gruntów budujących profile glebowe oraz specyficzne właściwości hydrologiczne tych profili. Stwierdzono, że głównymi czynnikami kształtującymi bilans wody na stokach są warunki orograficzne, udział części szkieletowych w profilu glebowym oraz warunki drzewostanowe. W związku z oddziaływaniem tych czynników równania ubytku zapasu wody w glebie muszą uwzględniać: 1) dopływ energii słonecznej nad korony drzew oraz współczynnik przenoszenia energii wewnątrz drzewostanu, 2) prędkość wiatru nad i wewnątrz drzewostanu, 3) składowe bilansu wody w atmosferze, 4) zróżnicowanie właściwości hydrologicznych profilu glebowego traktowanego jako kontinuum, 5) właściwości wodnych gruntów budujących profile glebowe, ze szczególnym uwzględnieniem materii organicznej.

Reviewers:

Prof. Antoni T. Miler

Assist. prof. Józef Mosiej 